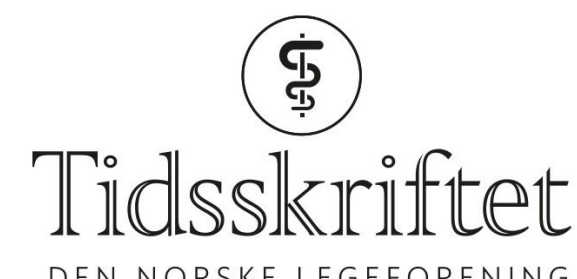

DEN NORSKE LEGEFORENING

\title{
Aplastisk anemi
}

KLINISK OVERSIKT

\section{SOFIE HAGESTANDE}

E-post: sofie.hagestande@hotmail.com

Det medisinske fakultet

Universitetet i Bergen

Hun har bidratt med utforming av artikkelen, litteraturs $\emptyset \mathrm{k}$ og utarbeiding av figurer.

Sofie Hagestande er siste års medisinstudent. Hun er selv blitt diagnostisert med aplastisk anemi. Forfatteren har fylt ut ICMJE-skjemaet og oppgir ingen interessekonflikter.

\section{ANN KRISTIN KVAM}

Avdeling for blodsykdommer

Oslo universitetssykehus, Rikshospitalet

Hun har bidratt med revisjon av manus og klinisk relevant informasjon innen hematologi.

Ann Kristin Kvam er ph.d., spesialist i hematologi og overlege.

Forfatteren har fylt ut ICMJE-skjemaet og oppgir ingen interessekonflikter.

\section{INGER MARIE BOWITZ LOTHE}

Avdeling for patologi

Oslo universitetssykehus, Radiumhospitalet

Hun har bidratt med fremstilling og mikroskopisk undersøkelse av benmargsbiopsier og klinisk relevant informasjon innen patologi.

Inger Marie Bowitz Lothe er spesialist i patologi og overlege.

Forfatteren har fylt ut ICMJE-skjemaet og oppgir ingen interessekonflikter.

\section{HILDE K. GJELBERG}

Avdeling for patologi

Haukeland universitetssjukehus

Hun har bidratt med fremstilling og mikroskopisk undersøkelse av benmargsbiopsier og klinisk relevant informasjon innen patologi.

Hilde K. Gjelberg er spesialist i patologi og overlege.

Forfatteren har fylt ut ICMJE-skjemaet og oppgir ingen interessekonflikter.

\section{$\varnothing Y S T E I N$ BRUSERUD}

Klinisk institutt 2

Universitetet i Bergen

og

Medisinsk avdeling

Haukeland universitetssjukehus

Han har bidratt med revisjon av manus og klinisk relevant informasjon innen hematologi. $\emptyset$ ystein Bruserud er dr.med., spesialist i indremedisin og i blodsykdommer og professor. Forfatteren har fylt ut ICMJE-skjemaet og oppgir ingen interessekonflikter. 
Han har bidratt med idé, utforming, litteratursøk og utarbeiding av figurer i artikkelen. Tor Henrik Anderson Tvedt er spesialist i blodsykdommer og overlege med klinisk erfaring med aplastisk anemi.

Forfatteren har fylt ut ICMJE-skjemaet og oppgir ingen interessekonflikter.

Aplastisk anemi er en sjelden form for benmargssvikt karakterisert av tap av hematopoetiske stamceller, cellefattig benmarg og utilstrekkelig produksjon av blodceller. Ubehandlet er tilstanden svært alvorlig med kort forventet levetid, men en stor andel av pasientene blir friske med immunsuppresjon eller allogen stamcelletransplantasjon.

Aplastisk anemi er en livstruende form for benmargssvikt som gir tap av hematopoetiske stamceller uten at man kan påvise en mangeltilstand eller infiltrasjon av ondartede celler $\mathrm{i}$ benmargen (1). Tilstanden er sjelden, og insidensen varierer med etnisitet fra ca. 2,5 per millioner innbyggere/år hos europeere til ca. 7,5 per millioner innbyggere/år. Insidensen varierer med alder og er høyest hos yngre (10-25 år) og personer over 6o år (2).

Formålet med artikkelen er å gi en kort oversikt over årsaker, diagnostikk, prognose og behandlingsmuligheter ved aplastisk anemi. Artikkelen er basert på ikke-systematisk søk i PubMed og egne kliniske erfaringer.

\section{Årsaker}

Det er vanlig å dele årsakene til aplastisk anemi inn i ervervede og medfødte (2). Av de ervervede årsakene mener man at det $\mathrm{i}$ ca. $60 \%$ av tilfellene er en autoimmun underliggende tilstand som fører til destruksjon av hematopoetiske stamceller (2). Det viktigste holdepunktet for dette er at man ved immunsuppressiv behandling ser en delvis eller fullstendig regenerasjon av benmargsfunksjonen. Risiko for aplastisk anemi ser også ut til å være knyttet til noen spesifikke vevstyper. Vevstype ser også ut til å predikere respons på immunsuppressiv behandling (2).

Siden det ikke finnes en diagnostisk test som kan påvise et immunologisk angrep på stamceller, klassifiseres de aller fleste tilfellene som idiopatiske. Man tror imidlertid at en del årsaker til aplastisk anemi fortsatt ikke er beskrevet (1).

Aplastisk anemi er beskrevet etter behandling med flere ulike medikamenter. Da mange av beskrivelsene kun er enkeltrapporter, kan sykdomsutviklingen være tilfeldig, men ved noen medikamenter ser det ut til å være en klar sammenheng. Peroralt inntak av kloramfenikol gir en spesielt høy risiko for aplastisk anemi, som er angitt til å være 1 per 20 ooo eksponerte (3). Topisk bruk av kloramfenikol er ikke assosiert med økt risiko. Flere antiepileptika som felbamat, karbamazepin, fenytoin og valproat er også knyttet til utvikling av aplastisk anemi (4). Hvordan disse medikamentene utløser tilstanden, er ikke kjent, men både trigging av en immunologisk respons og forskjeller i metabolisme med økt toksisk effekt av metabolitter, har vært diskutert (5). Medikamentelt utløst aplastisk anemi må skilles fra en reversibel suppresjon av hematopoese under medikamentell behandling, som f.eks. ved langvarig bruk av betalaktamantibiotika. Enkelte medikamenter må dermed seponeres før man med sikkerhet kan stille diagnosen.

Aplastisk anemi er også observert etter eksponering for kjemikalier med toksisk benmargseffekt (f.eks. sennepsgass, benzen) eller langtidseksponering for store doser radioaktiv stråling (1).

Noen virussykdommer kan gi forbigående eller vedvarende hypoplasi av benmargen. Blant annet kan parvovirus B19, hepatittvirus, hiv, Epstein-Barr-virus og cytomegalovirus føre til uttalt aplasi (6).

Fanconis anemi og telomersykdommer er to medfødte tilstander som er assosiert med aplastisk anemi, også ved debut i høy alder (6). Begge tilstandene skyldes genetiske defekter i DNA-reparasjonssystemet. Ved Fanconis anemi ses ofte misdannelser i armer eller føtter, kortvoksthet og café-au-lait-flekker i tillegg til aplastisk anemi. Hos pasienter uten misdannelser kan pancytopeni være første symptom på sykdommen. 
Telomersykdommer er genetiske defekter i telomerasekomplekset som fører til tap av vitale DNA-segmenter, slik at stamcellereserven i flere organer går tom. Dermed får man en form for tidlig aldring, med blant annet utvikling av aplastisk anemi som konsekvens. Pasienter med Fanconis anemi og telomersykdommer har økt risiko for kreft i hud og slimhinner, de tåler cellegiftbehandling dårligere og trenger en spesialtilpasset behandling og oppfølging. Alle pasienter med aplastisk anemi skal derfor undersøkes for om de kan ha en av disse tilstandene.

\section{Diagnostikk, inndeling og prognose}

Aplastisk anemi er en eksklusjonsdiagnose. For å stille diagnosen må det påvises pancytopeni og hypocellulær benmarg, og andre årsaker til benmargshypoplasi må utelukkes. Diagnosen stilles på grunnlag av cytopeni i to av tre cellerekker, hypoplasi av benmargen med cellularitet lavere enn $25-30$ \% samt at annen årsak til benmargssvikt er utelukket. Ut fra grad av cytopeni deles tilstanden inn i ikke- alvorlig, alvorlig og veldig $\operatorname{alvorlig(tabell~1)(6).~}$

\section{Tabell 1}

Gradering av aplastisk anemi (6)

\begin{tabular}{|c|c|c|c|}
\hline & Ikke-alvorlig & Alvorlig & Veldig alvorlig \\
\hline $\begin{array}{l}\text { Cellularitet } \mathrm{i} \\
\text { benmarg }\end{array}$ & $<25-30 \%$ & $<25-30 \%$ & $<25-30 \%$ \\
\hline $\begin{array}{l}\text { Grad av } \\
\text { cytopeni }\end{array}$ & $\begin{array}{c}\text { Ingen av kriteriene } \\
\text { oppfylt for alvorlig } \\
\text { eller veldig alvorlig } \\
\text { aplastisk anemi }\end{array}$ & $\begin{array}{c}\text { Minst to av } \\
\text { følgende: } \\
\text { Nøytrofile } \\
\text { granulocytter }<0,5 . \\
10^{9} / \mathrm{L} \\
\text { Trombocytter }<20 . \\
10^{9} / \mathrm{L} \\
\text { Retikulocytter }<20 . \\
10^{9} / \mathrm{L}\end{array}$ & $\begin{array}{c}\text { Som ved alvorlig } \\
\text { aplastisk anemi, men } \\
\text { nøytrofile granulocytter } \\
<0,2 \cdot 10^{9} / \mathrm{L}\end{array}$ \\
\hline
\end{tabular}

Det finnes ingen enkel test for å stille diagnosen (6). I praksis vil den først bli aktuell etter at man har tatt en benmargsbiopsi. Sammenlignet med normal benmarg (figur 1) vil man ved aplastisk anemi finne uttalt hypoplasi av hematopoese, og margrom domineres av fettceller (figur 2). I biopsien kan man samtidig vurdere om det foreligger annen primær malign benmargssykdom, lymfoproliferativ sykdom, metastaser, inflammatoriske eller infeksiøse prosesser eller tilstand med økt produksjon av blod, som ved hemolytisk anemi (figur 3 ).

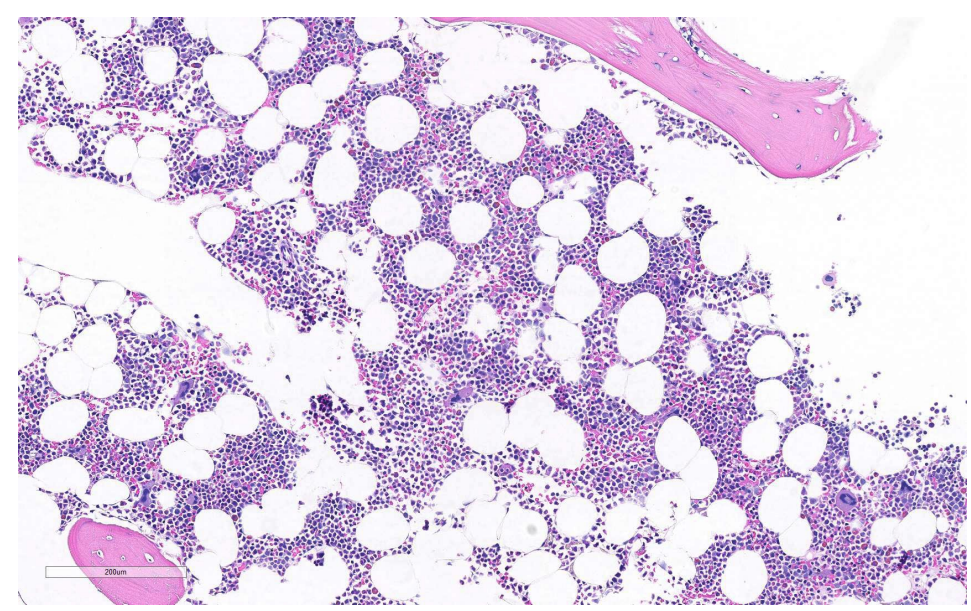

Figur 1 Normocellulcer benmarg. 


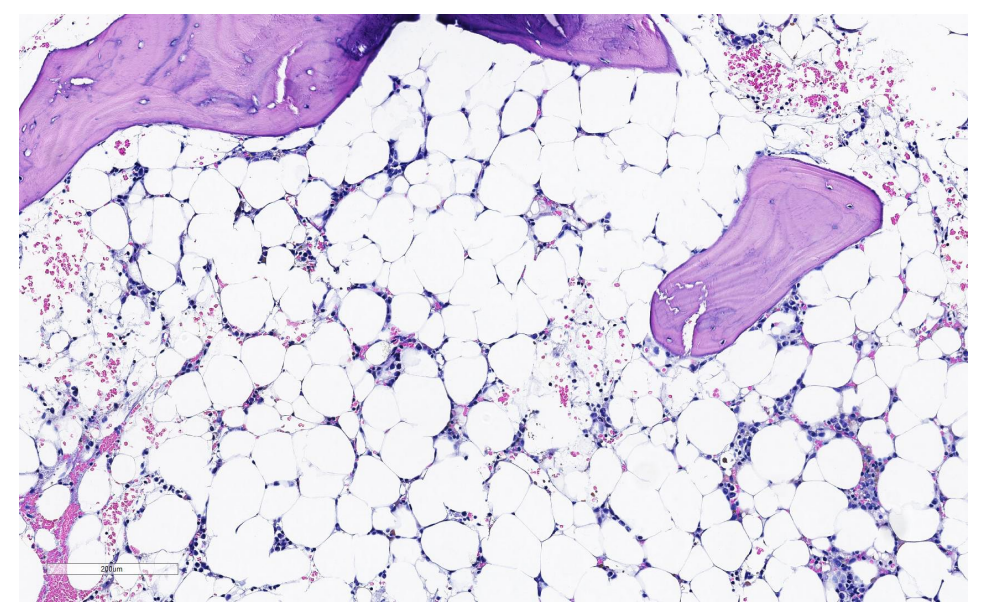

Figur 2 Sterkt hypocellulcer benmarg hos en pasient med veldig alvorlig aplastisk anemi. Her sees ingen organisert hematopoese, og andelen fettceller er betydelig økt.

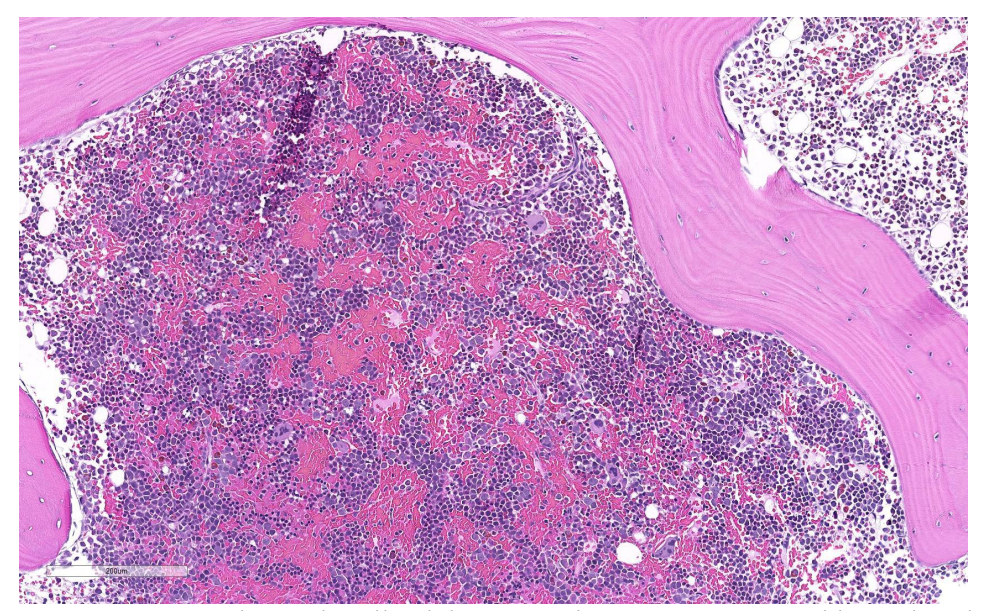

Figur 3 Ncer maksimalt cellerik benmarg hos en pasient med hemolytisk anemi. Her sees sterkt dominerende erytropoese.

Cytogenetisk undersøkelse av benmargen vil avdekke kromosomforandringer, mens væskestrømcytometri av blod er viktig for å undersøke om det foreligger en paroksystisk nattlig hemoglobinuri (PNH)-klon, en ervervet tilstand hvor leukocytter, erytrocytter og trombocytter mister spesifikke proteiner på celleoverflaten og dermed blir mindre immunogene (6). Videre gjøres virusdiagnostikk, målrettet familie- og medikamentanamnese og undersøkelser for å identifisere misdannelser assosiert med Fanconis anemi eller tegn på tidlig aldring assosiert med telomersykdommer.

Den viktigste differensialdiagnosen til aplastisk anemi er myelodysplastisk syndrom. Dette er et samlebegrep for en rekke ondartede benmargssykdommer som medfører pancytopeni og risiko for overgang til akutt myelogen leukemi (7). Ved den hypoplastiske subtypen finner man pancytopeni med svært få celler i benmargen. Funn av unormal modning av de hematopoetiske cellene ved histologisk undersøkelse er også karakteristisk for myelodysplastisk syndrom, men siden det både ved hypoplastisk myelodysplastisk syndrom og aplastisk anemi er svært få celler i benmargen, er denne distinksjonen vanskelig. Påvisbare genetiske avvik er de viktigste markørene som brukes for å skille mellom de to tilstandene. Noen spesifikke genetiske avvik, som tap av hele eller deler av kromosom 5, 7 eller 21 og trisomi av kromosom 8 eller 21, ansees som typiske for myelodysplastisk syndrom og taler mot diagnosen aplastisk anemi (8). Kromosomavvik kan også forekomme ved aplastisk anemi, da spesielt på kromosom 6 (9).

Ubehandlet har veldig alvorlig aplastisk anemi en ettårsmortalitet på 70 \% (10). Pasienter med ikke-alvorlig aplastisk anemi har bedre prognose og kan leve i mange år med transfusjon av trombocyttkonsentrat og erytrocyttkonsentrat ved blødning eller symptomgivende anemi. Livskvaliteten kan imidlertid være betydelig redusert. Alder påvirker både prognose og behandlingsvalg. Eldre har større risiko for infeksjon og tåler 
komplikasjoner ved immunsuppresjon eller stamcelletransplantasjon dårligere.

\section{Behandling}

Aplastisk anemi behandles først og fremst med allogen stamcelletransplantasjon eller immunsuppresjon til de pasientene som vurderes å kunne tåle slik behandling.

Ved allogen stamcelletransplantasjon gir man pasienten forbehandling med antitymocyttglobulin (ATG) kombinert med cytostatika og/eller stråling før man infunderer stamceller høstet fra benmarg fra en frisk giver. I tillegg til

infeksjonskomplikasjoner er det ved stamcelletransplantasjon risiko for avstøting av givers benmarg (ca. 1-5\% vil miste transplantatet og få residiv av aplastisk anemi) og transplantatmot-vert-sykdom (GVHD) - en inflammatorisk tilstand i forskjellige organer (11). For å forhindre utviklingen av transplantat-mot-vert-sykdom, som kan gi betydelig redusert livskvalitet og i verste fall død, er det etter transplantasjonen behov for langvarig immunsuppresjon med ciklosporin.

Fordelene ved stamcelletransplantasjon sammenlignet med immunsuppresjon alene er en mye større sannsynlighet for varig remisjon. Ulempen er $ø \mathrm{kt}$ risiko for redusert livskvalitet og død grunnet kronisk transplantat-mot-vert-sykdom.

Immunsuppressiv behandling gis i form av antitymocyttglobulin og ciklosporin (11). Behandlingen fører til langvarig lymfopeni og forbigående økt infeksjonsrisiko. Pasientene settes derfor samtidig på ett års profylaktisk behandling med bactrim mot Pneumocystis jirovecii-pneumoni (PJP) og valaciklovir mot herpes zoster-virus (HZV).

Behandlingsrespons i form av $\emptyset$ kte perifere blodverdier i en eller flere av cellerekkene kan komme sent, inntil 6-8 måneder etter at behandlingen er gitt. 50-80\% av pasientene vil imidlertid kunne starte nedtrapping av ciklosporin etter 3-6 måneder. På lengre sikt vil kun ca. 30 \% oppnå fullstendig normalisering av verdiene, $15-25 \%$ vil ikke kunne slutte med ciklosporin og 10-20\% vil oppleve tilbakefall av aplastisk anemi (12).

Risikoen for de forskjellige komplikasjonene er avhengig av pasientens alder og hvor god donor man har tilgjengelig. Valg av behandling er dermed en nytte-risiko-vurdering basert på disse faktorene. Unntaket er pasienter med arvelige former for aplastisk anemi som bør behandles med allogen stamcelletransplantasjon. Generelt om behandlingsvalg sier man at personer under 20 år tilbys behandling med allogen stamcelletransplantasjon, og personer i alderen 20-40 år tilbys transplantasjon hvis man har funnet en donor som passer godt (10, 11, 13). Personer over 40 år tilbys som regel i første omgang immunsuppresjon.

Mens det tar 1-2 måneder å utrede en pasient for allogen stamcelletransplantasjon, kan behandling med antitymocyttglobulin og ciklosporin igangsettes umiddelbart. I noen tilfeller starter man denne behandlingen parallelt med søket etter donor. Ettersom transplantasjonsutredningen tar såpass lang tid, taper man lite på å prøve immunsuppresjon, selv om effekten av denne er sen. Ved manglende respons på antitymocyttglobulin og ciklosporin etter 120 dager går man i gang med transplantasjon hos pasienter under 40 år som har donor. Immunsuppresjon er førstevalg hos yngre pasienter med ikke-alvorlig aplastisk anemi, siden denne behandlingen gir liten risiko for tidlig død og en stor andel pasienter oppnår en tilstrekkelig respons (14).

Noen pasienter er for gamle eller skrøpelige til å tåle behandling med allogen stamcelletransplantasjon eller immunsuppresjon. Behandling med testosteronderivater eller eltrombopag kan bedre benmargsfunksjonen noe (15).

Førstevalget er danazol, som er et testosteronderivat som gir lite maskuliniserende bivirkninger. Danazol ser ut til å være spesielt effektiv hos pasienter med telomersykdommer (16). Eltrombopag er et lite molekyl som stimulerer trombopoetinreseptoren og gir respons hos ca. $40-50 \%$ av pasientene med aplastisk anemi (17). Nyere studier viser at dersom man legger eltrombopag til antitymocyttglobulin og ciklosporin, økes responsraten til nesten $90 \%$ (17). 
Det er også viktig å huske på at pasienter med aplastisk anemi skal ha samme støttebehandling som andre pasienter med benmargssvikt, det vil si blodtransfusjoner med bestrålte blodprodukter etter behov, profylakse mot invasive soppinfeksjoner ved langtidssteroidbehandling og antibakterielle midler ved infeksjoner.

\section{Konklusjon}

Aplastisk anemi er en sjelden, alvorlig form for benmargssvikt karakterisert av pancytopeni og benmargshypoplasi. Vanligste årsak er et immunologisk angrep mot hematopoetiske stamceller, mens en liten andel pasienter har en arvelig årsak. Diagnosen er en eksklusjonsdiagnose, hvor man etter nøye anamnese samt benmargsbiopsi, immunfenotyping og genetiske analyser utelukker andre årsaker. Behandlingen avhenger av alvorlighetsgrad, pasientens alder og donorsituasjon. Allogen stamcelletransplantasjon er aktuelt hos unge friske pasienter med tilgjengelig donor. Immunsuppresjon gir bedring av perifere blodverdier hos ca. $60 \%$ og er et godt alternativ til pasienter som ikke er aktuelle for allogen stamcelletransplantasjon. Der verken transplantasjon eller immunsuppresjon er aktuelt, kan danazol eller eltrombopag gi bedring av blodverdier og livskvalitet.

\section{LITTERATUR:}

1. Luzzatto L, Risitano AM. Advances in understanding the pathogenesis of acquired aplastic anaemia. Br J Haematol 2018; 182: 758-76. [PubMed][CrossRef]

2. Wang L, Liu H. Pathogenesis of aplastic anemia. Hematology 2019; 24: 559-66. [PubMed][CrossRef] 3. Wallerstein RO, Condit PK, Kasper CK et al. Statewide study of chloramphenicol therapy and fatal aplastic anemia. JAMA 1969; 208: 2045-50. [PubMed][CrossRef]

4. Handoko KB, Souverein PC, van Staa TP et al. Risk of aplastic anemia in patients using antiepileptic drugs. Epilepsia 2006; 47: 1232-6. [PubMed][CrossRef]

5. Babushok DV, Li Y, Roth JJ et al. Common polymorphic deletion of glutathione S-transferase theta predisposes to acquired aplastic anemia: Independent cohort and meta-analysis of 609 patients. Am J Hematol 2013; 88: 862-7. [PubMed][CrossRef]

6. Killick SB, Bown N, Cavenagh J et al. Guidelines for the diagnosis and management of adult aplastic anaemia. Br J Haematol 2016; 172: 187-207. [PubMed][CrossRef]

7. Kasahara S, Hara T, Itoh $\mathrm{H}$ et al. Hypoplastic myelodysplastic syndromes can be distinguished from acquired aplastic anaemia by bone marrow stem cell expression of the tumour necrosis factor receptor. Br J Haematol 2002; 118: 181-8. [PubMed][CrossRef]

8. Scheinberg P, Young NS. How I treat acquired aplastic anemia. Blood 2012; 120:1185-96.

[PubMed][CrossRef]

9. Ogawa S. Clonal hematopoiesis in acquired aplastic anemia. Blood 2016; 128: 337-47.

[PubMed][CrossRef]

10. Young NS. Aplastic anaemia. Lancet 1995; 346: 228-32. [PubMed][CrossRef]

11. Bacigalupo A. How I treat acquired aplastic anemia. Blood 2017; 129:1428-36. [PubMed][CrossRef]

12. Saracco P, Quarello P, Iori AP et al. Cyclosporin A response and dependence in children with acquired aplastic anaemia: a multicentre retrospective study with long-term observation follow-up. $\mathrm{Br}$ J Haematol 2008; 140: 197-205. [PubMed][CrossRef]

13. Young NS, Bacigalupo A, Marsh JC. Aplastic anemia: pathophysiology and treatment. Biol Blood Marrow Transplant 2010; 16: S119-25. [PubMed][CrossRef]

14. Marsh J, Schrezenmeier H, Marin P et al. Prospective randomized multicenter study comparing cyclosporin alone versus the combination of antithymocyte globulin and cyclosporin for treatment of patients with nonsevere aplastic anemia: a report from the European Blood and Marrow Transplant (EBMT) Severe Aplastic Anaemia Working Party. Blood 1999; 93: 2191-5. [PubMed][CrossRef]

15. Scheinberg P. Activity of eltrombopag in severe aplastic anemia. Blood Adv 2018; 2:3054-62. 
[PubMed][CrossRef]

16. Townsley DM, Dumitriu B, Liu D et al. Danazol treatment for telomere diseases. N Engl J Med 2016; 374: 1922-31. [PubMed][CrossRef]

17. Townsley DM, Scheinberg P, Winkler T et al. Eltrombopag added to standard immunosuppression for aplastic anemia. N Engl J Med 2017; 376: 1540-50. [PubMed][CrossRef]

Publisert: 14. desember 2020. Tidsskr Nor Legeforen. DOI: 10.4045/tidsskr.20.0139

Mottatt 18.2.2020, første revisjon innsendt 29.6.2020, godkjent 18.9.2020.

(C) Tidsskrift for Den norske legeforening 2020. Lastet ned fra tidsskriftet.no 